\title{
BOILER DENGAN SISTEM PENGAMAN PANAS SEBAGAI ALAT PERAGA PENDIDIKAN DI SMK TINTA MAS BEKASI
}

\section{BOILER WITH HEAT PROTECTION SYSTEM AS EDUCATIONAL PROPAT SMK TINTA MAS BEKASI}

\author{
${ }^{1)}$ Adhes Gamayel, ${ }^{2}$ Sinka Wilyanti, ${ }^{1)}$ Ade Sunardi \\ ${ }^{1)}$ Program Studi Teknik Mesin ${ }^{2)}$ Program Studi Teknik Elektro \\ Sekolah Tinggi Teknologi Jakarta \\ Jl. Jatiwaringin Raya No. 278 Pondok Gede 17411 \\ 1)email : adhes@sttj.ac.id
}

\begin{abstract}
ABSTRAK
Alat peraga merupakan penunjang kurikulum dalam kegiatan belajar mengajar. Fungsinya untuk menciptakan kondisi belajar yang efektif, meningkatkan motivasi belajar, mempermudah peserta didik memahami materi pelajaran, dan membantu siswa dalam berpikir logis. Salah satu contoh alat peraga yang berbasis teknik mesin dan teknik elektronika adalah boiler dengan sistem pengaman panas.SMK Tinta Mas memiliki jurusan teknik elektronika dan teknik mesin. Permasalahan yang dimiliki oleh kedua jurusan tersebut adalah (1) belum adanya alat peraga tentang mesin-mesin industri, (2) Siswa belum mengerti tentang cara kerja boiler, dan (3) Siswa belum mengerti tentang sistem pengaman panas. Tujuan kegiatan ini adalah memberi pengetahuan kepada siswa tentang peralatan elektronika pada mesin-mesin industri. Metode pelaksanaan yang dilakukan pada kegiatan ini adalah (1) penyuluhan cara kerja boiler dan sistem pengaman panas, (2) pelatihan praktek pengoperasian boiler dan sistem pengaman panas. Diawal kegiatan siswa diberi pre-test dan di akhir kegiatan diberi post test untuk melihat hasil dari keberhasilan metode ini. Hasil dari kegiatan ini yaitu bertambahnya pengetahuan dan motivasi belajar siswa tentang sistem pengaman panas dan cara kerja boiler. Disamping itu, siswa memiliki ketrampilan dalam pengoperasian boiler dan sistem pengaman panas.
\end{abstract}

Kata Kunci: Alat Peraga, Boiler, Sistem Pengaman Panas, Pelatihan

\begin{abstract}
The prop is a supporting curriculum in teaching and learning activities. Its function is to create effective learning conditions, increase learning motivation, making it easier for student to understand the subject matter, and helping them in logical thinking. One example of props based on mechanical engineering and electronics engineering is a boiler with a heat protection system. SMK Tinta Mas has majoring in electronics engineering and mechanical engineering. The problems possessed by the two departments are (1) the absence of props about industrial machinery, (2) Students do not understands about the workings of boilers, and (3) Students do not understand the heat safety system. The general purposes adding student knowledge about electronic equipment on industrial machines. The implementation methods undertaken in this activity are (1) explaining of boiler work and heat protection system, (2) training practical of boiler operation and heat protection system. At the beginning of the activity students were given a pre-test and at the end of the activity were given a post test to see the success of this method. The result of this activity is the increasing of student's knowledge and learning motivation about heat protection system and boiler work. In addition, students have skills in the operation of boilers and heat protection systems.
\end{abstract}

Keywords: Props,Boiler, Heat Protection System, Training 


\section{PENDAHULUAN}

Alat peraga merupakan penunjang kurikulum dalam kegiatan belajar mengajar. Fungsinya untuk menciptakan kondisi belajar yang efektif dalam memotivasi belajar, mempermudah peserta didik dalam memahami materi pelajaran, dan membantu siswa dalam berpikir logis (Suwardi,Firmiana \& Rokhayati, 2016; Juwairiah, 2013). Alat peraga harus dibuat sebaik mungkin, menarik untuk diamati, dan mendorong siswa untuk penasaran sehingga diharapkan motivasi belajarnya semakin meningkat (Suwardi, Firmiana \& Rokhayati, 2016)

Alat peraga juga dapat digunakan sebagai penunjang dalam pemenuhan kompetensi siswa. Pengoperasian dan perawatan instalasi boiler merupakan salah satu kompetensi dasar di Sekolah Menengah Kejuruan (SMK). Boiler berfungsi mengubah air menjadi uap dengan cara pemanasan.Untuk menjaga keamanan pengoperasian boiler dan mencegah bahaya yang ditimbulkan, maka perlu dilakukan perawatan secara berkala. Selain itu perlu ditambahkan peralatan elektronika seperti kontrol otomatis sebagai pengaman panas yang menandakan bahwa kapasitas uap telah melebihi batas.

SMK Tinta Mas yang beralamat di jl Asem Raya No.1 Ciketing Mustika Jaya Bekasi Timur memiliki jurusan teknik elektronika dan teknik mesin. Permasalahan yang dimiliki oleh kedua jurusan tersebut adalah (1) belum adanya alat peraga tentang mesin-mesin industri, (2) Siswa belum mengerti tentang cara kerja boiler, (3) belum mengerti tentang sistem pengaman panas. Berdasarkan hal tersebut, maka perlu alat peraga yang berbasis keilmuan teknik mesin dan teknik elektronika berupa boiler dengan sistem pengaman panas.

Tujuan kegiatan ini adalah meningkatkan pengetahuan siswa tentang peralatan elektronika pada mesin-mesin industri

\section{METODE PELAKSANAAN}

Metode pelaksanaan yang dilakukan pada kegiatan ini secara garis besar ada dua kegiatan yaitu (1) penyuluhan cara kerja boiler dan sistem pengaman panas, (2) pelatihan praktek pengoperasian boiler dan sistem pengaman panas. Diawal kegiatan diberikan latihan soal (pre-test) tentang boiler dan cara kerjanya. Di akhir kegiatan dilaksanakan latihan soal akhir (post-test). Kedua hasil latihan soal ini dibandingkan untuk diketahui tingkat keberhasilan dari adanya pelatihan boiler dan sistem pengaman panas. Skema alat peraga dapat dilihat pada gambar 1 dibawah ini.

Gambar.1 Boiler dengan sistem pengaman panas

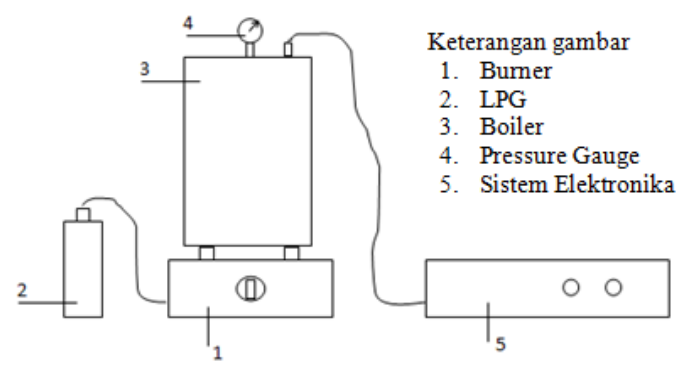

\section{HASIL DAN PEMBAHASAN}

Hasil dari kedua tahapan pelaksanaan kegiatan Ipteks bagi Masyarakat ini adalah :

\section{Meningkatnya pengetahuan siswa tentang boiler dan sistem pengaman panas}

Sebelum diadakan penyuluhan, dilakukan pre-test dengan pertanyaan mengenai definisi, cara kerja, bagian, fungsi per bagian, dan manfaat dari boiler. Dilanjutkan pertanyaan tentang efek uap air terhadap boiler, cara mengontrol uap air 
dan cara merawat boiler. Dari pertanyaan tersebut siswa belum mampu menjawab dengan baik. Hal ini terlihat pada tabel 1 , dimana rata-rata siswa hanya mampu menjawab 57,3\% dari semua pertanyaan.

Tabel.1. Rangkuman Hasil Latihan soal

\begin{tabular}{lcc}
\hline \multicolumn{1}{c}{ Uraian } & Pre-test & Post-test \\
\hline Nilai terendah & 45 & 75 \\
Nilai Tertinggi & 65 & 95 \\
Mean & 57,3 & 83 \\
Modus & 60 & 80 \\
Median & 60 & 82.5 \\
\hline
\end{tabular}

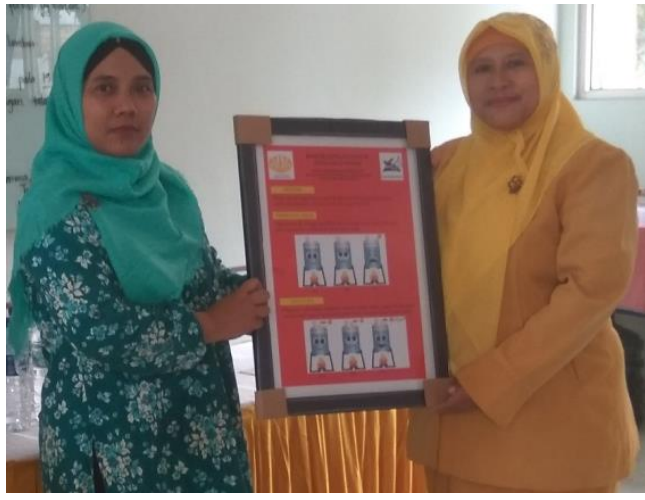

(a)
Oleh karena itu, dilakukan kegiatan penyuluhan dengan cara menjelaskan secara berurutan jawaban dari pertanyaan pre-test. Penjelasan yang diberikan berupa alur diagram dan poster. Siswa diberikan kesempatan untuk melihat dengan jelas alur diagram dan poster yang disajikan. Setelah mengerti, siswa diminta untuk menjelaskan kembali isi dari alur diagram dan poster tersebut.

Hasilnya terlihat saat dilakukan posttest, dimana rata-rata siswa dapat menjawab 83\% dari semua pertanyaan. Hasil ini sesuai dengan penelitian yang dilakukan oleh Mulyani, (2015) bahwa pembelajaran menggunakan alat peraga tiruan dapat meningkatkan hasil belajar siswa. Suasana penyerahan simbolis poster dan post-test siswa dapat dilihat pada gambar 2 .

Gambar 2. (a) Penyerahan alat peraga dan poster (b) Post-test alat peraga (dokumentasi penulis)

2. Meningkatnya motivasi belajar siswa saat praktek pengoperasian boiler dan sistem pengaman panas

Mayoritas siswa menjawab kurang tepat mengenai pertanyaan bagian-bagian boiler dan sistem pengaman panas. Oleh karena itu, dilakukan praktek pengoperasian alat peraga. Selama kegiatan praktek, siswa termotivasi untuk bertanya dan mencoba mengoperasikan alat peraga. Setiap siswa diberikan kesempatan untuk mencoba alat peraga, dan di setiap kesempatan tersebut muncul pertanyaan dari siswa. Hal ini menandakan bahwa motivasi siswa sangat tinggi untuk mengetahui secara detail tentang bagianbagian alat peraga dan cara pengoperasiannya. Motivasi ini menyebabkan nilai post-test lebih tinggi daripada nilai pre-test. Nilai yang sering 
Adhes Gamayel, Sinka Wilyanti, Ade Sunardi Boiler dengan Sistem Pengaman Panas sebagai Alat Peraga Pendidikan di SMK Tinta Mas Bekasi

didapat oleh siswa dalam post-test adalah 80.

Hal ini sesuai dengan penelitian dari Kurniawan (2012), dimana metode demonstrasi alat peraga dapat meningkatkan minat dan motivasi belajar siswa.

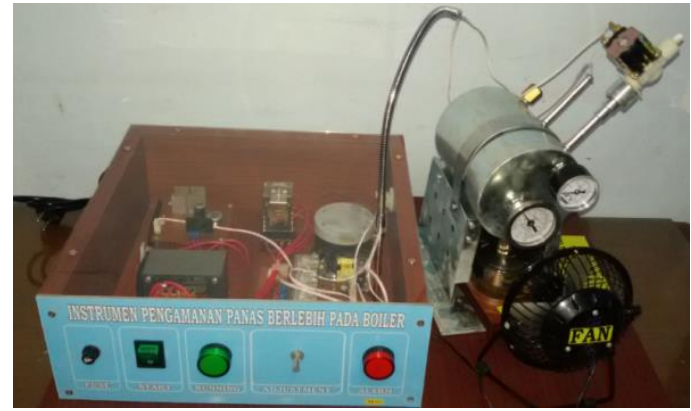

Gambar 3. Alat Peraga Boiler dan Sistem Pengaman Panas

(dokumentasi penulis)

\section{SIMPULAN}

Berdasarkan hasil kegiatan diatas, dapat disimpulkan bahwa pengetahuan boiler dan sistem pengaman panas bagi siswa SMK Tinta Mas meningkat dengan kegiatan penyuluhan dan pelatihan. Adanya Peningkatan minat dan motivasi belajar Siswa SMK Tinta Mas terhadap boiler dan sistem pengaman panas dengan adanya praktek penggunaan alat peraga tersebut. Luaran kegiatan ini berupa alat peraga yang terdiri dari boiler dan sistem pengaman panas.

\section{UCAPAN TERIMA KASIH}

Terima kasih disampaikan kepada DP2M Ditjen Dikti yang telah memberikan dana hibah IbM untuk kegiatan pengabdian masyarakat ini.

\section{DAFTAR PUSTAKA}

Juwairiah. (2013). Alat Peraga dan Media Pembelajaran Kimia.Visipena, (4), $1,1-13$

Kurniawan, P. V. (2012). Penerapan Metode Demonstrasi Berbantuan Alat Peraga Untuk Meningkatkan Minat Dan Motivasi Siswa Dalam Pembelajaran Fisika. Jurnal Penelitian Pembelajaran Fisika , (3), 2, 103-109.

Mulyani, T. (2015). Penggunaan alat peraga tiruan untuk meningkatkan pemahaman dan hasil belajar ipa siswa kelas IIISLBD1 YPACSurakarta Tahun 2011/2012. Seminar Nasional Pendidikan UNS\&ISPIJawa Tengah, (pp. 200205). Surakarta.

Suwardi, Firmiana, M. E., \& Rohayati. (2016). Pengaruh Penggunaan Alat Peraga terhadap Hasil Pembelajaran Matematika pada Anak Usia Dini. Jurnal Al-azhar Indonesia Seri Humaniora , (2), 4, 297-305. 